\title{
CAS-NETL-PNNL CEP Program Final Report
}
DL King
JE Rainbolt
KA Spies
K Zhang

March 2014

Pacific Northwest

NATIONAL LABORATORY

Proudly Operated by Battelle Since 1965 


\title{
DISCLAIMER
}

This report was prepared as an account of work sponsored by an agency of the United States Government. Neither the United States Government nor any agency thereof, nor Battelle Memorial Institute, nor any of their employees, makes any warranty, express or implied, or assumes any legal liability or responsibility for the accuracy, completeness, or usefulness of any information, apparatus, product, or process disclosed, or represents that its use would not infringe privately owned rights. Reference herein to any specific commercial product, process, or service by trade name, trademark, manufacturer, or otherwise does not necessarily constitute or imply its endorsement, recommendation, or favoring by the United States Government or any agency thereof, or Battelle Memorial Institute. The views and opinions of authors expressed herein do not necessarily state or reflect those of the United States Government or any agency thereof.

\author{
PACIFIC NORTHWEST NATIONAL LABORATORY \\ operated by \\ BATTELLE \\ for the \\ UNITED STATES DEPARTMENT OF ENERGY \\ under Contract DE-AC05-76RL01830
}

Printed in the United States of America

Available to DOE and DOE contractors from the Office of Scientific and Technical Information,

P.O. Box 62, Oak Ridge, TN 37831-0062;

ph: (865) 576-8401

fax: (865) 576-5728

email: reports@adonis.osti.gov

Available to the public from the National Technical Information Service

5301 Shawnee Rd., Alexandria, VA 22312 ph: (800) 553-NTIS (6847)

email: ordersantis.gov <http://www.ntis.gov/about/form.aspx>

Online ordering: http://www.ntis.gov

This document was printed on recycled paper. 


\title{
CAS-NETL-PNNL CEP Program Final Report
}

\author{
DL King JE Rainbolt \\ KA Spies K Zhang
}

March 2014

Prepared for

the U.S. Department of Energy

under Contract DE-AC05-76RL01830

Pacific Northwest National Laboratory

Richland, Washington 99352 


\section{Contents}

Task 3.3 - Warm Syngas Cleanup and Catalytic Processes for Syngas Conversion to Fuels.............. v

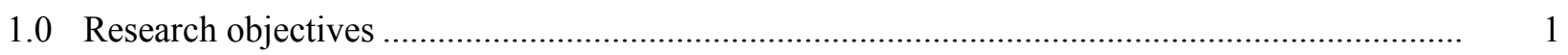

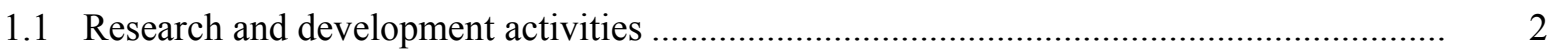

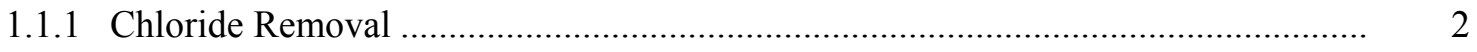

1.1.2 Sulfur Gas Removal .................................................................................. 2

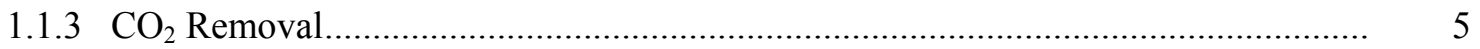

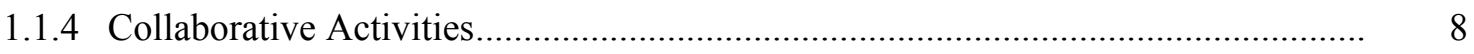

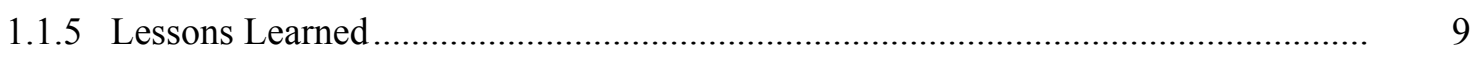

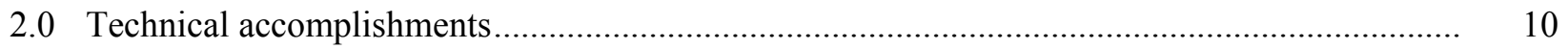

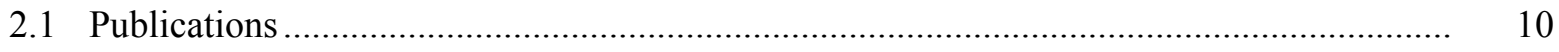

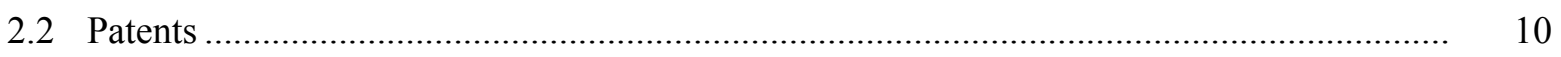

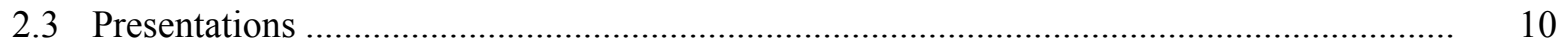

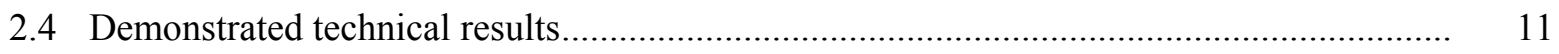

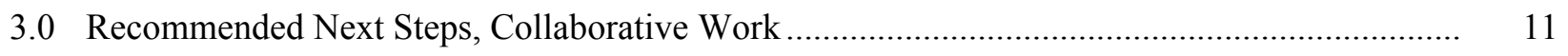

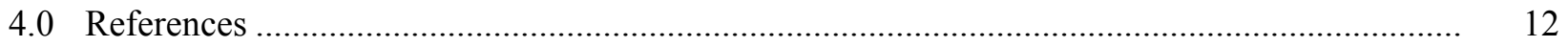




\section{Task 3.3 - Warm Syngas Cleanup and Catalytic Processes for Syngas Conversion to Fuels}

\section{Subtask 2: Integrated Warm Syngas Cleanup and $\mathrm{CO}_{2}$ Capture System}

This collaborative joint research project is in the area of advanced gasification and conversion, within the Chinese Academy of Sciences (CAS)-National Energy Technology Laboratory (NETL)-Pacific Northwest National Laboratory (PNNL) Memorandum of Understanding. The goal is the development and testing of an integrated warm syngas cleanup process. This effort is focused on an advanced, integrated system for capture and removal of alkali, sulfur, $\mathrm{PH}_{3}, \mathrm{AsH}_{3}$, chloride, and $\mathrm{CO}_{2}$, leading to a future process demonstration at a CAS gasification facility. Syngas produced by gasification can be used for production of fuels (Fischer-Tropsch, SNG, mixed alcohols), chemicals $\left(\mathrm{MeOH}, \mathrm{NH}_{3}\right)$, and hydrogen for fuel cells and Integrated Gasification Combined Cycle IGCC. To employ this syngas, especially for synthesis reactions, contained impurities must be removed to sub-ppmv levels [1]. Commercially available approaches to remove contaminant species suffer from inefficiencies, employing solvents at ambient or lower temperature along with backup sacrificial sorbents, whereas syngas utilization occurs at higher temperatures. The efficiency and economics syngas utilization can be significantly improved if all the contaminants and $\mathrm{CO}_{2}$ are removed at temperatures higher than the chemical synthesis reaction temperatures $\left(>250^{\circ} \mathrm{C}\right)[2]$.

Due to lack of third year funding support for the project, research activities were curtailed prior to reaching the final deliverables. This report documents work completed with the available funding, and meets the request of the NETL office for project closeout. 


\subsection{Research objectives}

This project had as its primary objectives:

- Cleanup all catalyst-poisoning contaminants from warm coal or biomass-derived syngas in the warm temperature range $\left(300-500^{\circ} \mathrm{C}\right)$.

- Remove $\mathrm{CO}_{2}$ from the purified, warm syngas, in conjunction with water gas shift, to produce hydrogen or syngas with the appropriate $\mathrm{H}_{2} / \mathrm{CO}$ ratio for chemical or fuel synthesis.

These objectives can be seen in Figure 1, and were met with the funding provided.

- Demonstrate an integrated process for hydrogen production at a CAS site at the end of this 3-year project.

This objective, a demonstration at the CAS facility in China, was not met due to loss of third year project funding.

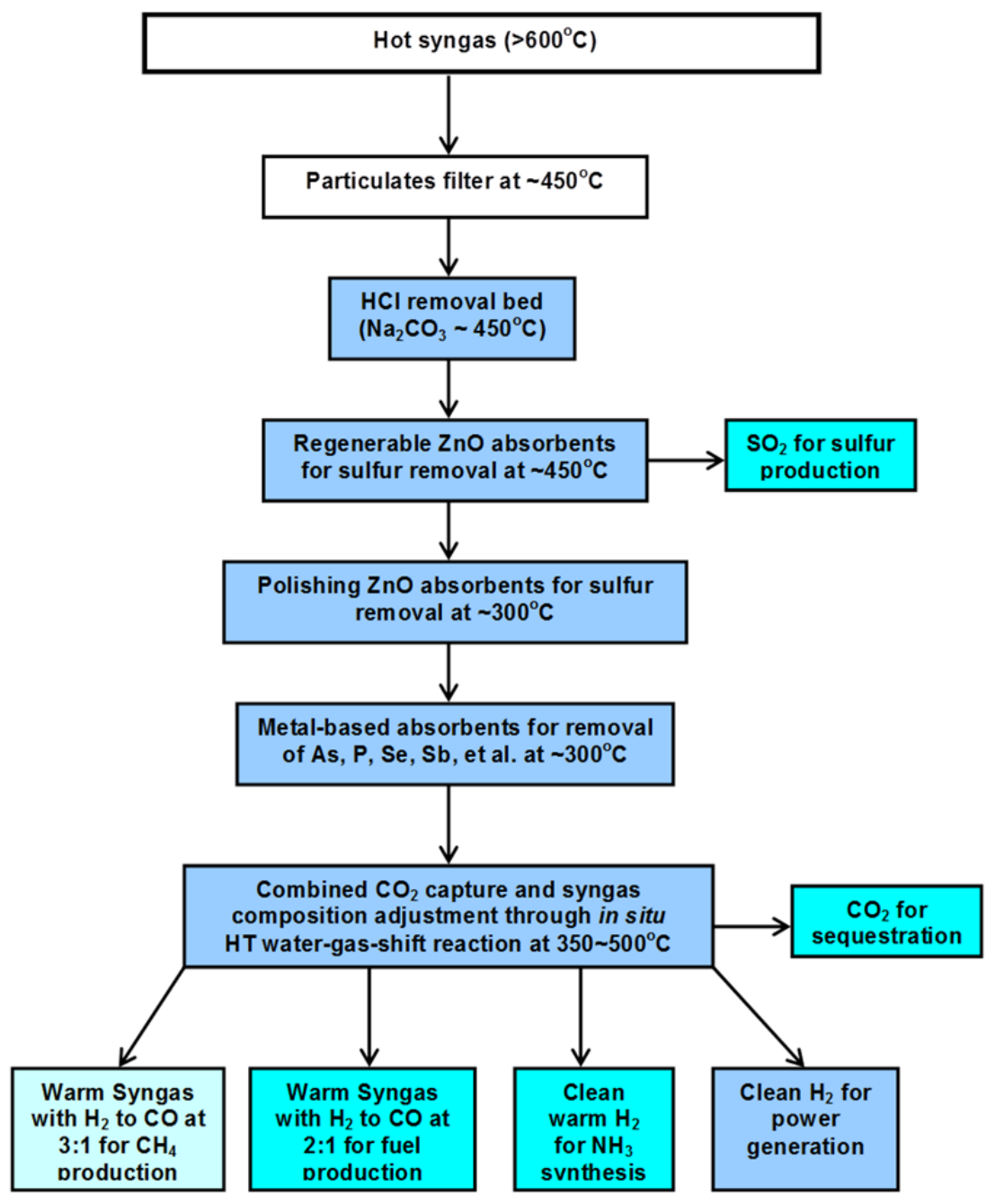

Figure 1. Warm gas cleanup and $\mathrm{CO}_{2}$ capture, representing the PNNL part of the collaboration. The boxes in the last row show the options for use of syngas depending upon $\mathrm{H}_{2} / \mathrm{CO}$ ratio. 


\subsection{Research and development activities}

The following activities were carried out with support from the CAS-NETL-PNNL joint project.

\subsubsection{Chloride Removal}

Through the use of a packed fixed bed of sodium carbonate $\left(\mathrm{Na}_{2} \mathrm{CO}_{3}\right)$, chloride (as $\mathrm{HCl}$ ) was removed through the formation of $\mathrm{NaCl}: 2 \mathrm{HCl}+\mathrm{Na}_{2} \mathrm{CO}_{3} \rightarrow 2 \mathrm{NaCl}+\mathrm{CO}_{2}+\mathrm{H}_{2} \mathrm{O}$, which is thermodynamically favorable. Figure 2 shows the results of tests for chloride removal, showing essentially quantitative removal, and that significant capacity toward chloride can be obtained at $450^{\circ} \mathrm{C}$ at space velocity as high as $80,000 \mathrm{hr}^{-1}$, although maximum chloride capacity of $50 \mathrm{wt} . \%$ was obtained at $20,000 \mathrm{hr}^{-1}$.

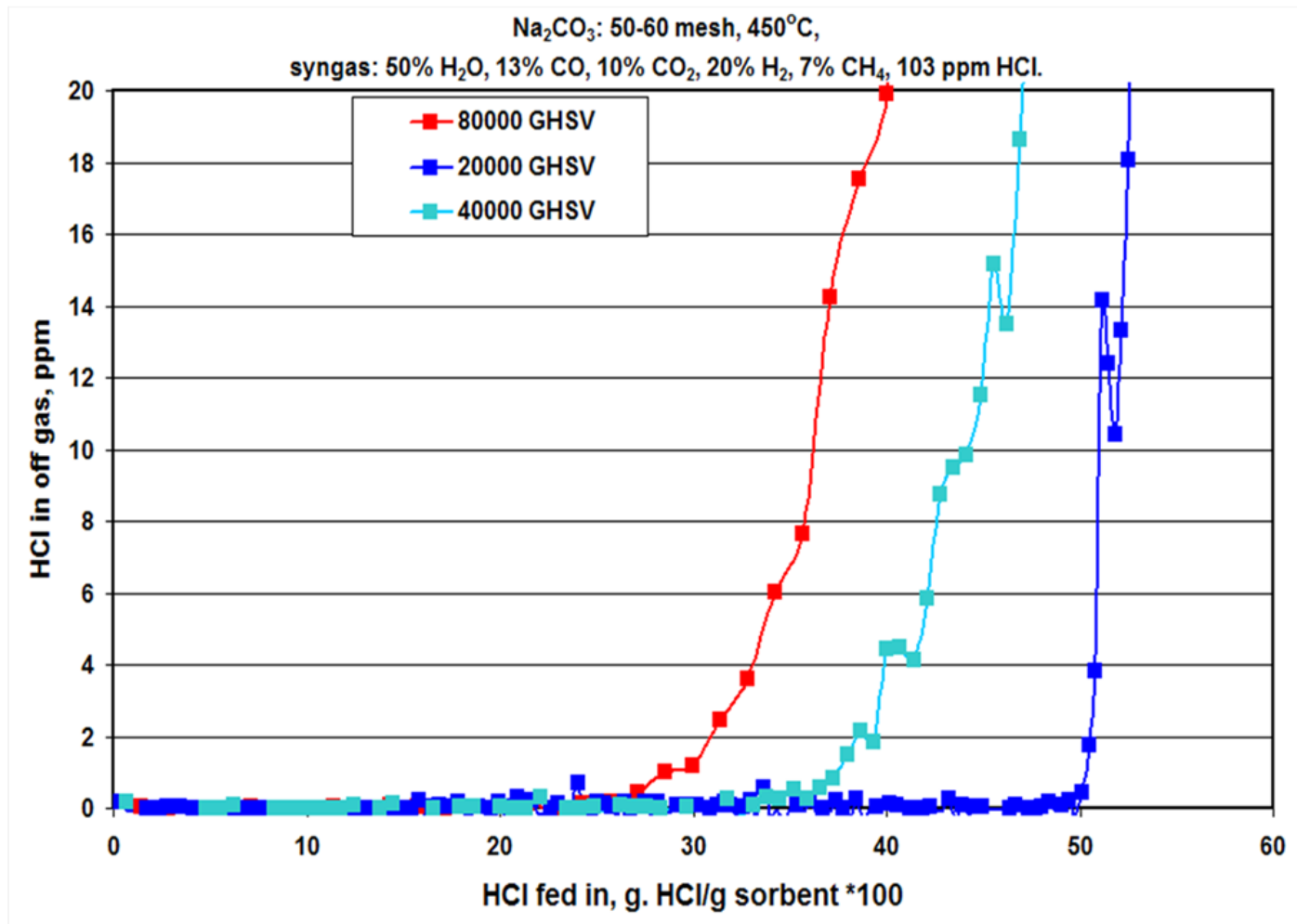

Figure 2. Effect of space velocity on absorption capacity for $\mathrm{HCl}$ by a solid bed of $\mathrm{Na}_{2} \mathrm{CO}_{3}$, operating at $450^{\circ} \mathrm{C}$, with a wet syngas feed.

\subsubsection{Sulfur Gas Removal}

Our work focused on development of sulfur gas removal based on a $\mathrm{ZnO}$-based absorbent. There are various forms of modified $\mathrm{ZnO}$, with many focusing on addition of $\mathrm{TiO}_{2}$ or other additives to allow $\mathrm{ZnO}$ to function more effectively at elevated temperatures $\left(\geq 500^{\circ} \mathrm{C}\right)$ without loss of $\mathrm{Zn}$ via reduction $[3,4]$. The $\mathrm{ZnO}$ absorbent we selected was provided by Sud Chemie (now Clariant), and contains $\sim 10 \mathrm{wt} . \%$ $\mathrm{Al}_{2} \mathrm{O}_{3}$. Despite the large amount of available literature, there was little to guide us in selection of operating parameters for our selected $\mathrm{ZnO}$ absorbent. This is, in part, the result of variations found in $\mathrm{H}_{2} \mathrm{~S}$ concentration in the feed, the water content, the absorbent composition and particle size, space 
velocity, and operating temperature in reported studies [5-7]. Moreover, in many cases information was not sufficiently detailed regarding sulfur gas slip and its identity $\left(\mathrm{H}_{2} \mathrm{~S}\right.$ or COS), when that slip was in the few ppmv range. These considerations guided the focus of this work.

Our efforts focused on identifying preferred operating conditions for adsorption of both of the sulfur gases $\left(\mathrm{H}_{2} \mathrm{~S}\right.$ and $\left.\mathrm{COS}\right)$ with $\mathrm{ZnO}$-based absorbents under warm temperature conditions. There has been a substantial amount of work published on $\mathrm{H}_{2} \mathrm{~S}$ absorption by $\mathrm{ZnO}$, although much less so with COS.

References indicate that $\mathrm{COS}$ first hydrolyzes to $\mathrm{H}_{2} \mathrm{~S}$ and is then absorbed by $\mathrm{ZnO}$, hence the need for $\mathrm{H}_{2} \mathrm{O}$ to be in the feed when COS is present; otherwise COS is not well captured by ZnO [8,9]. Literature also describes the role of acidic additives such as $\mathrm{Al}_{2} \mathrm{O}_{3}$ added to the $\mathrm{ZnO}$ to facilitate the conversion of $\mathrm{COS}$ to $\mathrm{H}_{2} \mathrm{~S}$ in the presence of water [10]. A significant effort was expended to determine the fate of COS in the presence of the $\mathrm{Al}_{2} \mathrm{O}_{3}$-modified $\mathrm{ZnO}$. We examined performance of the absorbent with both $\mathrm{H}_{2} \mathrm{~S}$ and $\mathrm{COS}$, on fresh and regenerated $\mathrm{ZnO}$, with and without water in the feed, and with and without syngas as a co-feed.

Operating at $450^{\circ} \mathrm{C}$, we carried out absorption experiments with COS, with either syngas or $\mathrm{N}_{2}$ as the primary gas, with either $\mathrm{H}_{2} \mathrm{O}$ present or absent in the feed. Under dry feed conditions with $\mathrm{N}_{2}$ as carrier gas, $\mathrm{COS}$ is completely absorbed by $\mathrm{ZnO}$ at $450^{\circ} \mathrm{C}$, as shown in Figure 3, with performance very comparable to $\mathrm{H}_{2} \mathrm{~S}$ absorption. We went to elaborate lengths to exclude water from the system. Therefore, we have no evidence that COS must be catalytically converted to $\mathrm{H}_{2} \mathrm{~S}$ prior to absorption, rather the opposite appears to be true with this absorbent.

H2S dry v. COS dry in N2 (1,000 ppm and 12K GHSV)

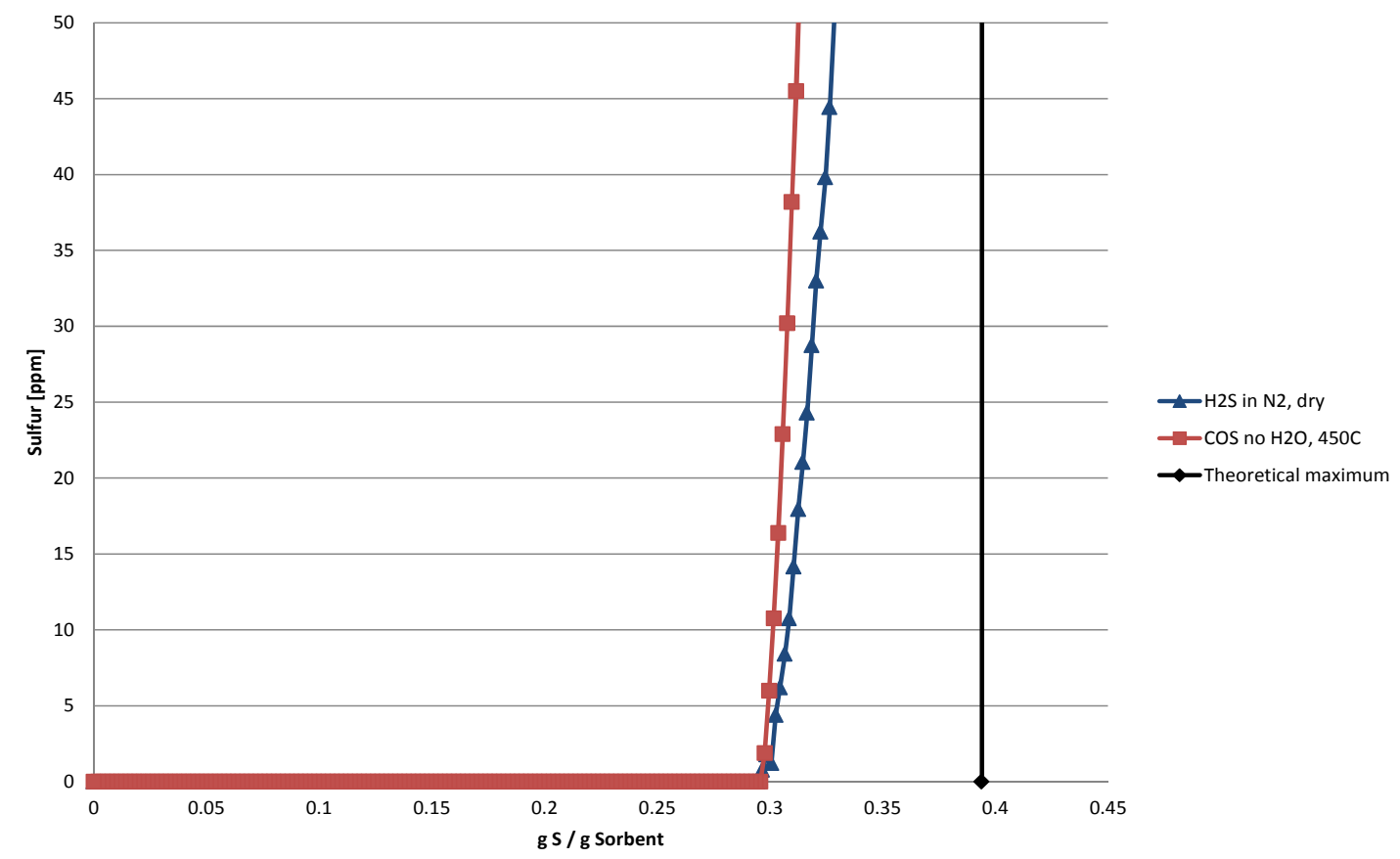

Figure 3. Comparative absorption behavior of $\mathrm{ZnO}$ toward $\mathrm{H}_{2} \mathrm{~S}$ and $\mathrm{COS}$. Conditions: $1000 \mathrm{ppmv}$ sulfur gas $\left(\mathrm{H}_{2} \mathrm{~S}\right.$ or COS $)$ in $\mathrm{N}_{2}$, dry, GHSV $=12,000$. Horizontal axis is $\mathrm{g} \mathrm{S}$ absorbed $/ \mathrm{g} \mathrm{ZnO}$ initial. 
On the other hand, we have seen that COS absorption is quite temperature dependent. Thus, although good performance is observed at $450^{\circ} \mathrm{C}$, whereas performance is poor at $200^{\circ} \mathrm{C}$, as shown in Figure 4. At these lower temperatures, COS hydrolysis most likely becomes the primary means COS removal because $\mathrm{H}_{2} \mathrm{~S}$ is effectively removed at $200^{\circ} \mathrm{C}$.

We also examined performance of $\mathrm{ZnO}$ following regeneration, and compared it with fresh $\mathrm{ZnO}$. Uniformly, we found that regenerated $\mathrm{ZnO}$ (by oxidation in $2 \% \mathrm{O}_{2} / 98 \% \mathrm{~N}_{2}$ at $600^{\circ} \mathrm{C}$ ) had good capacity toward $\mathrm{H}_{2} \mathrm{~S}$, but the sulfur slip was generally in the 3 to $5 \mathrm{ppmv}$ range. Capacity of the regenerated sample is reduced by about one third. Only in the case of fresh $\mathrm{ZnO}$ were we able to reach levels sulfur gas levels $<100 \mathrm{ppbv}$, as shown below in Figure 5. This confirms that an approach in which bulk $\mathrm{H}_{2} \mathrm{~S}$ is absorbed over regenerated $\mathrm{ZnO}$, with the small sulfur slip handled by a downstream polishing bed of fresh zinc oxide. [Note: the high $\mathrm{S}$ signal near $\mathrm{t}=0$ we have verified to be an artifact due to $\mathrm{H}_{2} \mathrm{~S}$ releasing from the walls of the stainless steel reactor.]

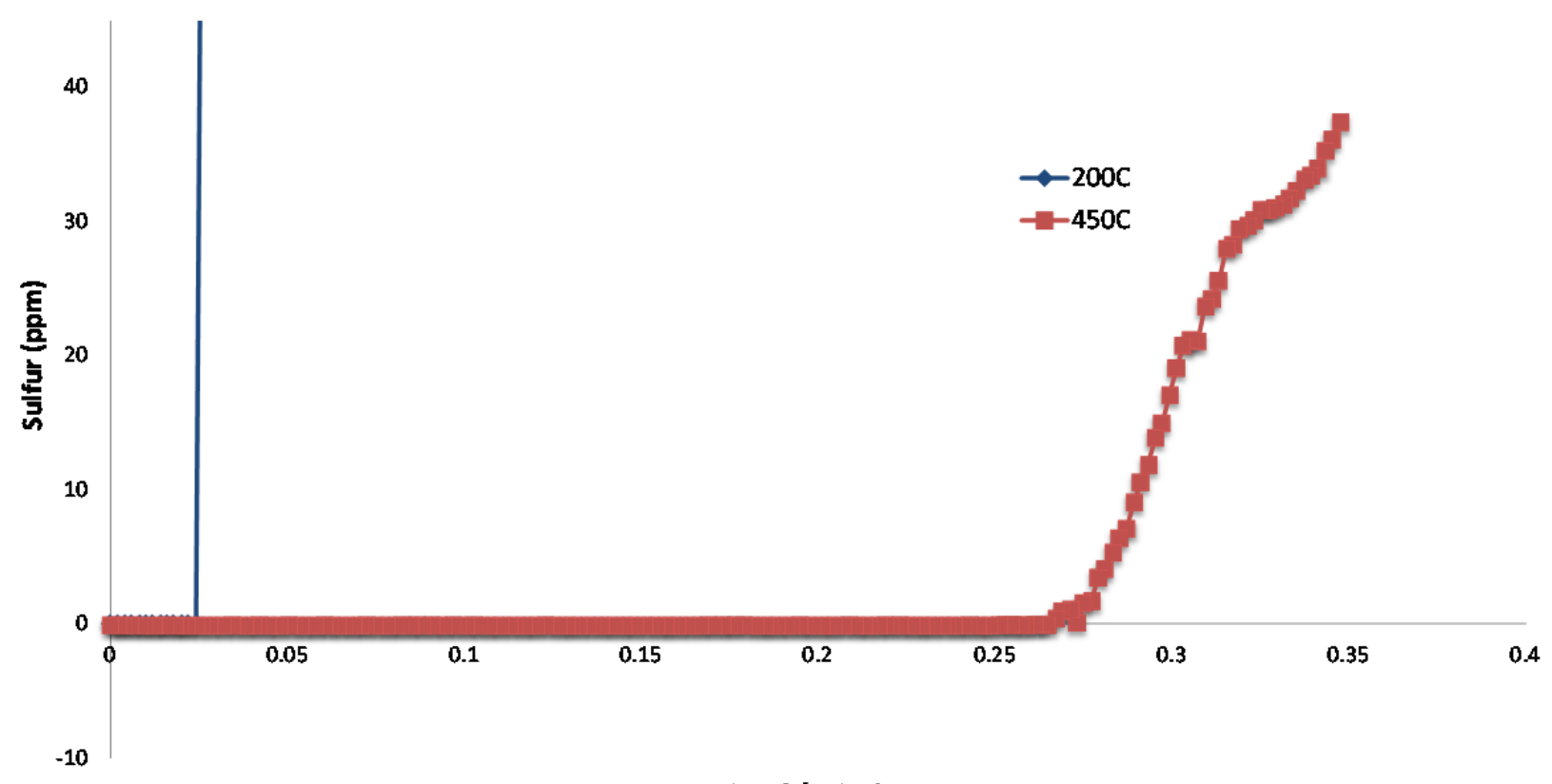

g S Fed / g Sorbent

Figure 4. Effect of temperature on COS absorption over ZnO, inert dry gas carrier, 24,000 GHSV, 500 ppmv $\mathrm{H}_{2} \mathrm{~S}$. 


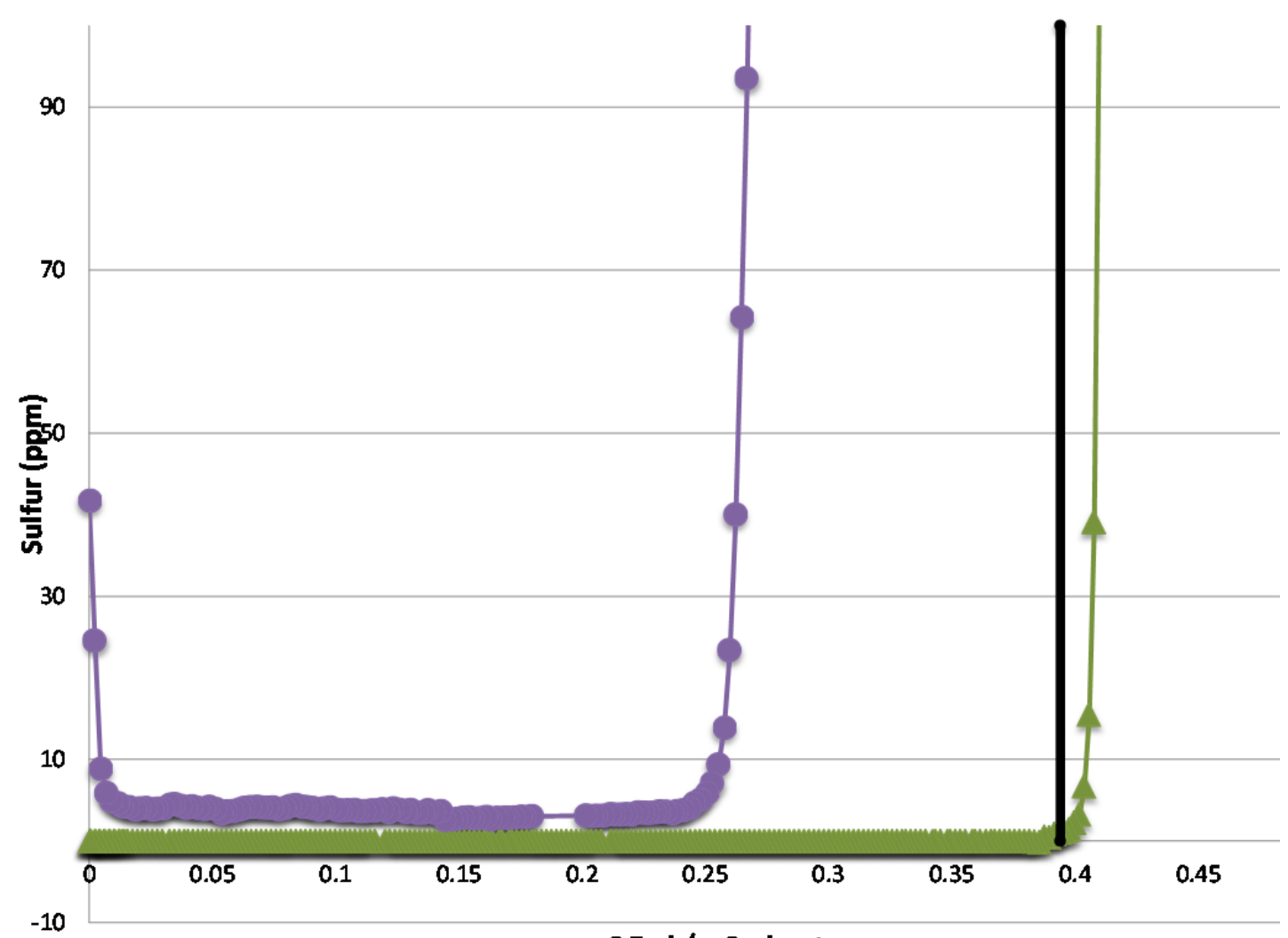

g S Fed / g Sorbent

Figure 5. $\mathrm{ZnO}$ with $\mathrm{H}_{2} \mathrm{~S}(1,000 \mathrm{ppm})$ in Syngas $\left(45 \% \mathrm{CO}, 28 \% \mathrm{H}_{2}, 14 \% \mathrm{CO}_{2}\right), 20 \% \mathrm{H}_{2} \mathrm{O}, 12 \mathrm{~K}$ GHSV, $450^{\circ} \mathrm{C}$. Green: fresh absorbent; blue; $1 \mathrm{x}$ regenerated absorbent.

\subsection{3 $\quad \mathrm{CO}_{2}$ Removal}

Previously, we described the regenerable absorption of $\mathrm{CO}_{2}$ by $\mathrm{MgO}-\mathrm{Na}_{2} \mathrm{CO}_{3}$, in the presence of $\mathrm{NaNO}_{3}$, which is a molten salt at the operating temperature of the experiment shown below $\left(400^{\circ} \mathrm{C}\right)[11]$. The first absorption cycle in Figure 6 shows a capacity of approximately $30 \mathrm{wt} \%$, while each of the subsequent cycles show a capacity of about $16.5 \mathrm{wt} \%$. XRD evidence has shown that during the first cycle, $\mathrm{MgCO}_{3}$ is formed, while in subsequent cycles only the double salt $\mathrm{MgCO}_{3}-\mathrm{Na}_{2} \mathrm{CO}_{3}$ is formed. The important detail to understand is that $\mathrm{CO}_{2}$ absorption occurs during the first cycle primarily during the heating up phase (i.e., at temperature below $400^{\circ} \mathrm{C}$. At $400^{\circ} \mathrm{C}, \mathrm{MgCO}_{3}$ decomposes to $\mathrm{MgO}$ and $\mathrm{CO}_{2}$ (regardless of the surrounding gas), whereas at $400^{\circ} \mathrm{C}$ the double salt is stable in $\mathrm{CO}_{2}$, but not in $\mathrm{N}_{2}$ (hence the effectiveness of a pressure swing approach). Although the high capacity through $\mathrm{MgCO}_{3}$ formation could not be sustained in this experiment, nevertheless it highlighted the fact that $\mathrm{MgO}$ can also absorb $\mathrm{CO}_{2}$ efficiently at temperatures $<400^{\circ} \mathrm{C}$ if a molten salt is present. This suggested that we study the system $\mathrm{MgO}+\mathrm{NaNO}_{3}+\mathrm{CO}_{2}$, without the presence of the alkali carbonate component. 


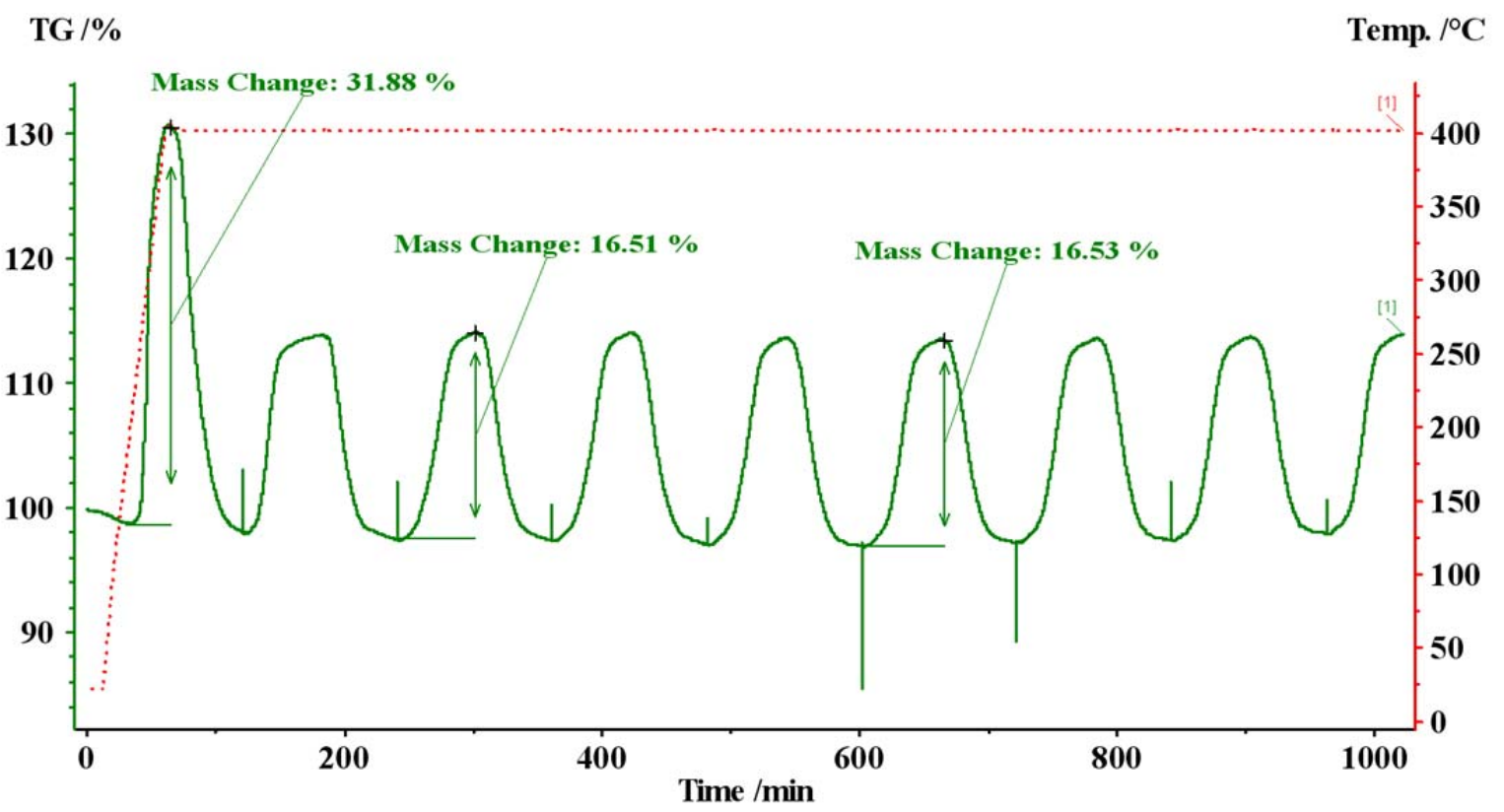

Figure 6. Multiple regeneration cycles of double salt $\left(\mathrm{MgO}-\mathrm{Na}_{2} \mathrm{CO}_{3}\right)$ with $\mathrm{CO}_{2}$, pressure swing (absorption- $100 \% \mathrm{CO}_{2}$; desorption- $100 \% \mathrm{~N}_{2}$ ) at $400^{\circ} \mathrm{C}$. The first absorption peak includes $\mathrm{MgO}$ conversion to $\mathrm{MgCO}_{3}$.

Absorption-desorption curves for $\mathrm{MgO}+\mathrm{NaNO}_{3}$ are shown in Figure 7. The operation in this case was a combined temperature-pressure swing. A first cycle absorption shows conversion of greater than $70 \%$ of the $\mathrm{MgO}$ to $\mathrm{MgCO}_{3}$. Subsequent cycles show decreasing capacity, which appears to line out at about $30 \% \mathrm{MgO}$ conversion. We have tried various conditions for absorption and regeneration of $\mathrm{MgO}$ $\mathrm{MgCO}_{3}$, but have not been able to find an absorbent that consistent converts $70 \%$ of $\mathrm{MgO}$ over multiple regeneration cycles. We do not know the cause, but suspect this may be related to the changing interaction between $\mathrm{MgO}-\mathrm{MgCO}_{3}$ and $\mathrm{NaNO}_{3}$ as the material particle properties change (sintering occurs).

\subsubsection{Effect of other molten salts}

Due to the fact that absorption of $\mathrm{CO}_{2}$ appears to occur over $\mathrm{MgO}$ once the $\mathrm{NaNO}_{3}$ melts, we examined the effect of using other salt mixtures and salt eutectic mixtures in place of $\mathrm{NaNO}_{3}$. In the experiment, the salt was first melted and cooled to re-solidify, and then $\mathrm{MgO}$ was placed physically on top of the salt. A Thermogravimetric TGA experiment was carried out in flowing $\mathrm{CO}_{2}$, in which the uptake of $\mathrm{CO}_{2}$ was recorded as a function of temperature. It can be seen in Figure 8 below that $\mathrm{CO}_{2}$ absorption begins at different temperatures with the different salt mixtures, in all cases coinciding with its melting point. Thus, we have found that very high conversion of $\mathrm{MgO}$ to $\mathrm{MgCO}_{3}$ can be obtained at temperatures below $200^{\circ} \mathrm{C}$. We note, however, that regeneration does not undergo a similar decrease in temperature, as that is limited by thermodynamics and $\mathrm{T}>400^{\circ} \mathrm{C}$ is required to regenerate $\mathrm{MgCO}_{3}$. 


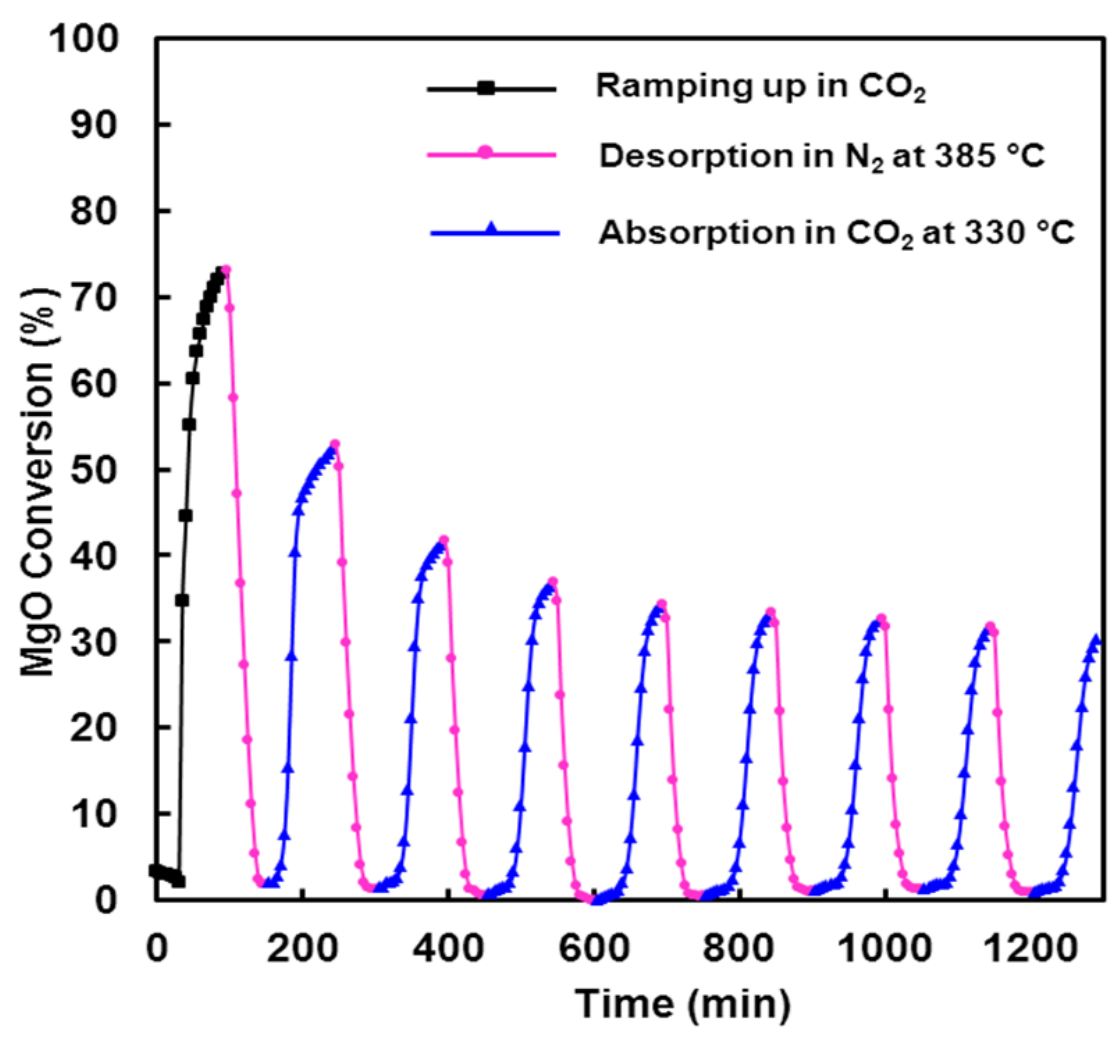

Figure 7. Cyclic $\mathrm{CO}_{2}$ absorption test of $20 \% \mathrm{NaNO}_{3}+80 \% \mathrm{MgO}$ through temperature-pressure combined swing: $330^{\circ} \mathrm{C}$ in $\mathrm{CO}_{2}$ and $385^{\circ} \mathrm{C}$ in $\mathrm{N}_{2}$.

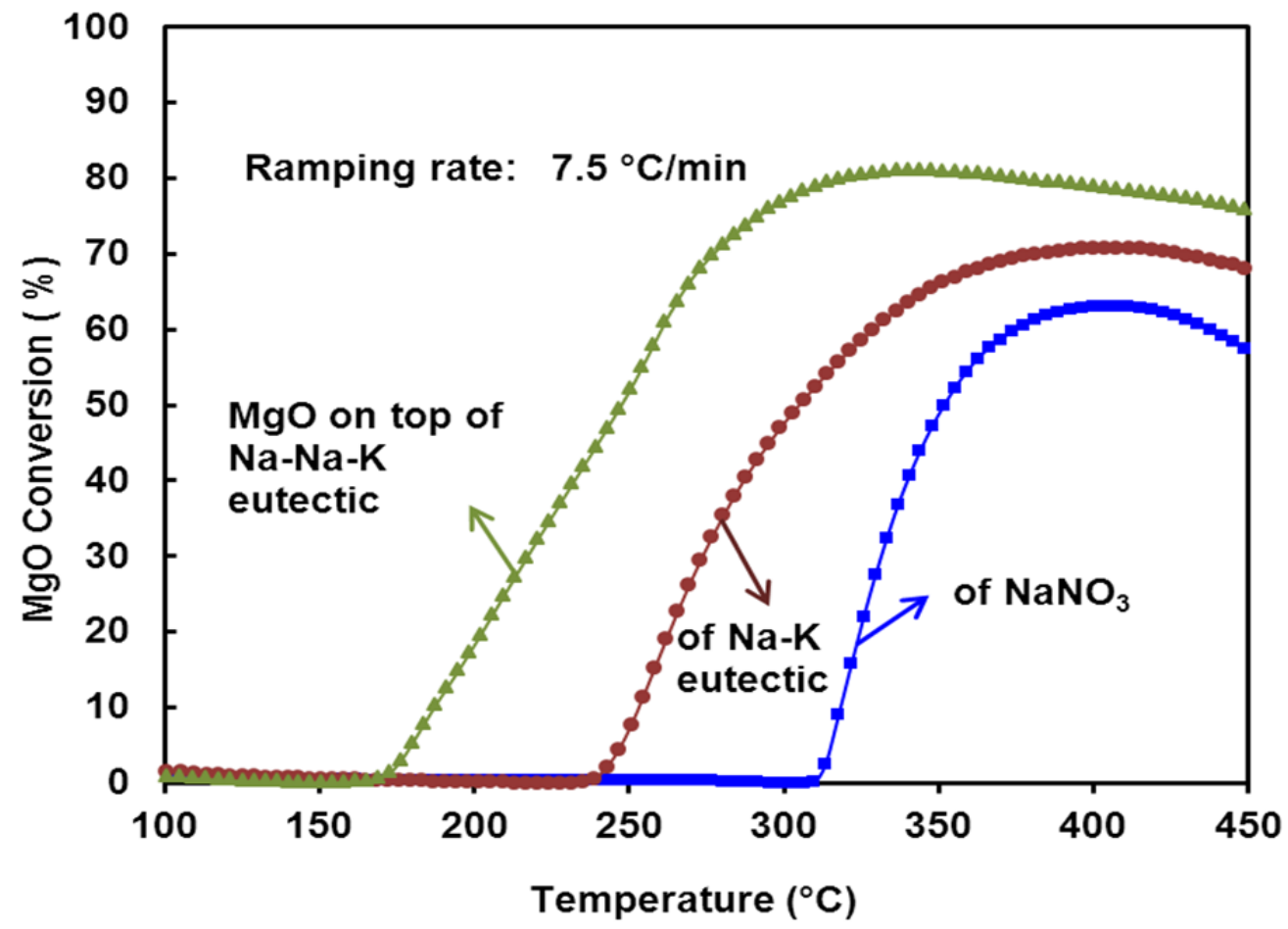

Figure 8. $\mathrm{CO}_{2}$ absorption on $\mathrm{MgO}$ with various nitrate, nitrate-nitrate, and nitrate-nitrite eutectic salts during non-isothermal heating in $\mathrm{CO}_{2}$. 


\subsubsection{Fixed bed absorption tests}

Although initial studies utilized TGA to demonstrate uptake and release of $\mathrm{CO}_{2}$, it is important that performance be demonstrated in fixed bed tests. Figure 9 shows a schematic of the conceptual experiment, carried out with pressurized syngas containing $\mathrm{CO}_{2}$. The absorbent was $\mathrm{MgO}-\mathrm{Na}_{2} \mathrm{CO}_{3}+$ $\mathrm{NaNO}_{3}$ double salt, carried out under pressure swing conditions at $400^{\circ} \mathrm{C}$.

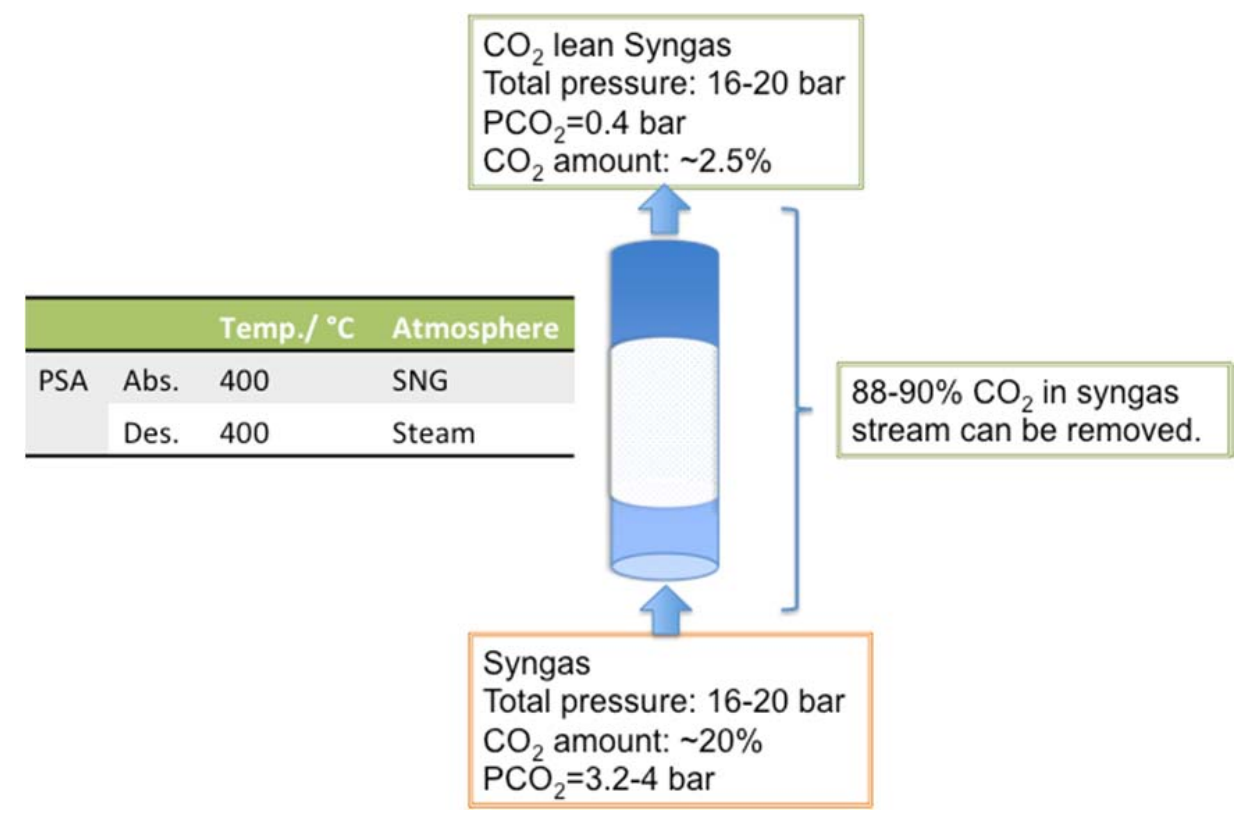

Figure 9. Schematic of fixed bed $\mathrm{CO}_{2}$ absorption tests.

The experimental details and results are shown in Figure 10. In this case, $\mathrm{CO}_{2}$ was separated from $\mathrm{H}_{2}$ (rather than syngas).

\subsubsection{Collaborative Activities}

\subsubsection{Collaborations with CAS}

In searching for an inexpensive capture material for $\mathrm{CO} 2$, CAS was interested in dolomite, a cheap mineral with composition $\mathrm{MgCa}\left(\mathrm{CO}_{3}\right)_{2}$. This material can be decomposed at elevated temperatures, to $\mathrm{MgO}-\mathrm{CaCO}_{3}$, but this material does not absorb $\mathrm{CO}_{2}$ over the temperature range 200 to $400^{\circ} \mathrm{C}$. Similar to the $\mathrm{MgO}-\mathrm{Na}_{2} \mathrm{CO}_{3}$ double salt, $\mathrm{MgO}-\mathrm{CaCO}_{3}$ was also found to absorb $\mathrm{CO}_{2}$ when a molten salt was added to the mixture. With this information and guidance, $\mathrm{CAS}$ was able to continue carrying out work on $\mathrm{CO}_{2}$ capture with that material, and also identified certain benefits in terms of increased kinetics, especially for decomposition of $\mathrm{MgCa}\left(\mathrm{CO}_{3}\right)_{2}$, by the presence of steam. We collaborated with CAS in demonstrating the efficacy of the $\mathrm{NaNO}_{3}$ addition, and also shared data on the effect of pressure on $\mathrm{CO}_{2}$ absorption. CAS published a paper based on their work on the dolomite system [12]. 
- 1.7 grams of absorbent was loaded for the test with a GHSV of $650 \mathrm{hr}^{-1}$.

- Test was conducted with $20 \% \mathrm{CO}_{2}$ in $\mathrm{H}_{2}$, at a pressure of 16 bar.

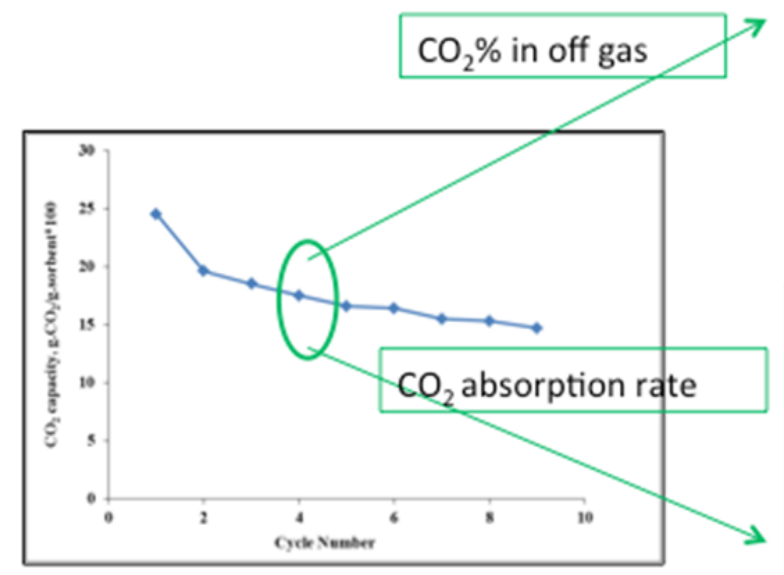

Multiple cycle absorption test in fixed bed reactor

- $80-90 \% \mathrm{CO}_{2}$ can be captured under a operation pressure of 16-20 bar.
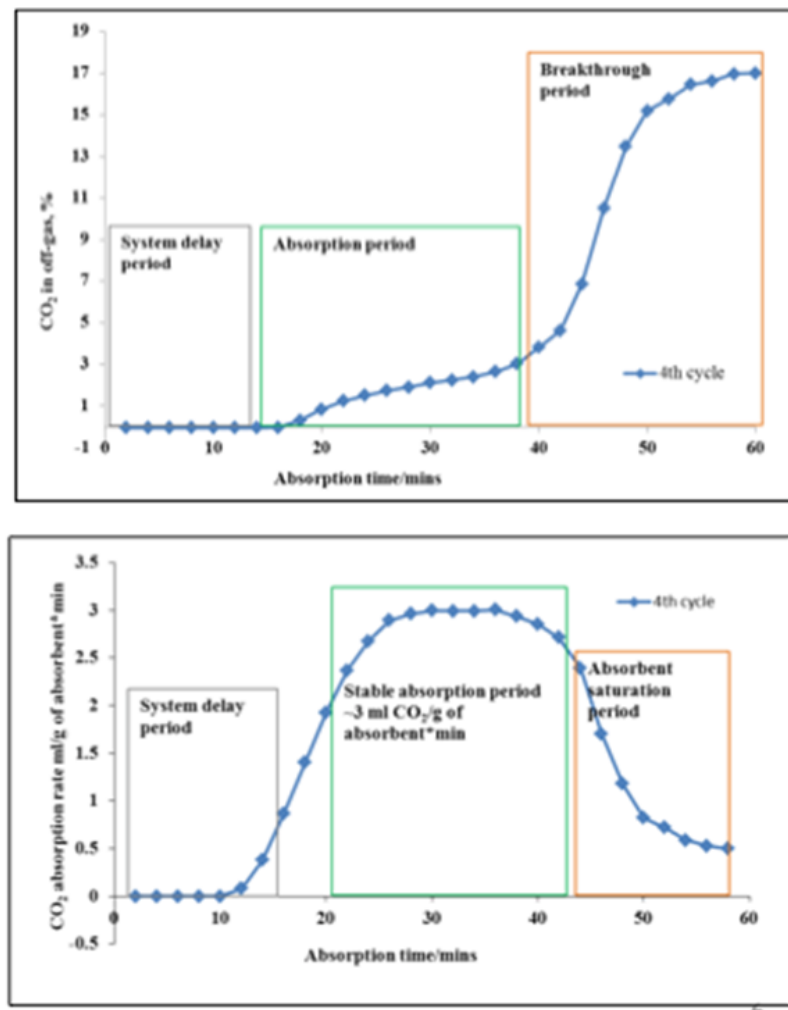

Figure 10. Demonstration of $\mathrm{CO} 2$ capture in fixed bed operation.

\subsubsection{Collaborations with NETL}

The collaborative work with NETL was primarily carried out with Dr. Yuhua Duan, who contributed to the overall knowledge of these systems through computational work. This included determining the thermodynamics $(\Delta \mathrm{H}$ and $\Delta \mathrm{G})$ of formation of $\mathrm{MgNa}_{2}\left(\mathrm{CO}_{3}\right)_{2}$ relative to $\mathrm{MgCO}_{3}+\mathrm{Na}_{2} \mathrm{CO}_{3}$. This was essential to our understanding of the operation of the double salt system for $\mathrm{CO}_{2}$ capture, and understanding why the $\mathrm{MgO}$ component did not also participate in $\mathrm{CO}_{2}$ absorption. Separately, Dr. Duan carried out calculations helping to interpret the role of $\mathrm{NaNO}_{3}$ in facilitating $\mathrm{CO}_{2}$ capture with $\mathrm{MgO}$. This resulted in several published papers, including two joint papers.

\subsubsection{Lessons Learned}

We have found working with CAS to be a positive experience. We were able to share $\mathrm{CO}_{2}$ absorption-desorption data on the dolomite system, with CAS providing capabilities to carry out TGA measurements at pressure and in the presence of steam, a capability which we did not have at PNNL. We also applied to a Funding Opportunity Announcement on $\mathrm{CO}_{2}$ capture in FY2013, and CAS was selected as a partner in the proposal along with the University of Connecticut. The proposal was not funded. We were careful to apply for patent coverage prior to sharing technical information on the role of nitrate salts with CAS. As expected, once CAS understood the importance of molten salts on $\mathrm{CO}_{2}$ capture with dolomite, they proceeded to carry out much of their work independently, leading to subsequent independent publications. 
In the case of NETL, we learned the importance of personal interactions. Although he was not funded directly through the CAS-NETL-PNNL agreement, Dr. Duan collaborated with us to provide a theoretical underpinning of the $\mathrm{CO}_{2}$ capture with double salt, based on thermodynamic calculations. He also collaborated with us to understand and quantify the energetic advantage of the use of molten salt on $\mathrm{CO}_{2}$ capture with $\mathrm{MgO}$. Several publications have come from this collaboration. Aside from Dr. Duan, our interactions with NETL on this project were minimal. Despite significant efforts, we were unable to generate any enthusiasm on the part of NETL for our work. It is likely that more effort on our part to share the excitement and discovery on this project might have generated greater interest.

\subsection{Technical accomplishments}

\subsection{Publications}

1. K. Zhang, X. Li, Y. Duan, D. L King, P. Singh, L. Li.; Roles of Double Salt Formation and $\mathrm{NaNO}_{3}$ in $\mathrm{Na}_{2} \mathrm{CO}_{3}$-Promoted $\mathrm{MgO}$ Absorbent for Intermediate Temperature $\mathrm{CO}_{2}$ Removal. Int. J. Greenhouse Gas Control, 12 (2013) 351-358.

2. K. Zhang, X. Li, W-Z. Li, A. Rohatgi, Y. Duan, P. Singh, L. Li, D. L. King; Phase TransferCatalyzed Fast $\mathrm{CO}_{2}$ Absorption by $\mathrm{MgO}$-Based Absorbents with High Cycling Capacity. Submitted to Advanced Materials Interfaces.

3. Y. Duan, K. Zhang, X. Li, D. L. King, B. Li, L. Zhao, Y. Xiao; ab initio Thermodynamic Study of the $\mathrm{CO}_{2}$ Capture Properties of $\mathrm{M}_{2} \mathrm{CO}_{3}(\mathrm{M}=\mathrm{Na}, \mathrm{K})$ - and $\mathrm{CaCO}_{3}$-Promoted $\mathrm{MgO}$ Sorbents Towards Forming Double Salts. Aerosol and Air Quality Research, doi: 10.4209/aaqr.2013.05.0178

\subsection{Patents}

1. Li, Liyu; King, David L.; Liu, Jun; Huo, Qisheng. Methods, systems, and devices for deep desulfurization of fuel gases. U.S. Patent 8,158,545 (2012).

2. K. Zhang, D. L. King, X. Li, L. Li, A. Rohatgi, P. Singh. System, Sorbents, and Processes for Capture and Release of $\mathrm{CO}_{2}$. Filed March, 2013.

\subsection{Presentations}

1. Keling Zhang, Xiaohong Shari Li, Wei-Zhen Li, Yuhua Duan, Aashish Rohatgi, Prabhakar Singh, David L. King; Phase Transfer-Catalyzed Fast $\mathrm{CO}_{2}$ Absorption by MgO-Based Absorbents with High Cycling Capacity. Poster presentation at the Philadelphia Catalysis Club, October 2013.

2. David L. King, Keling Zhang, X. Shari Li, Aashish Rohatgi; Warm $\mathrm{CO}_{2}$ Capture by MgO-Based Double Salts: Facilitation by Molten Alkali Nitrate Salts. Presented at the Clearwater Coal Conference, Clearwater, FL, June 2013.

3. Yuhua Duan, Dan Sorescu, David Lubke, Bingyun Li,, Keling Zhang, David King; Theoretical Screening of Mixed Solid Sorbents for $\mathrm{CO}_{2}$ Capture, 12th Ann. Conf. on Carbon Capture, Use, and Storage May 15, 2013, Pittsburgh, PA. 
4. Keling Zhang, David King, Xiaohong Shari Li, Yuhua Duan, Aashish Rohatgi, Prabhakar Singh; The Role of $\mathrm{NaNO}_{3}$ in Facilitating the Capture of $\mathrm{CO}_{2}$ by $\mathrm{MgO}$-based Oxides: An In Situ Examination of Surface and Interfacial Chemistry. Presented at the MRS 2013 Spring Conference.

5. K. Zhang, X. S. Li, R. Dagle, R. Xing, D. L. King, Y. Duan, P Singh; Carbon Capture-Promoted Syngas Utilization for Production of Fuels and Chemicals. Presented at the 2012 International Pittsburgh Coal Conference, Pittsburgh, PA; October 15-18, 2012.

6. X. S. Li, K. Zhang, L. Li, H. Chen, Y. Duan, P. Singh, D. L. King. MgO-CaCO 3 Double Salt Absorbents for $\mathrm{CO}_{2}$ Removal at $300-500^{\circ} \mathrm{C}$. Presented at the 2012 International Pittsburgh Coal Conference, Pittsburgh, PA; October 15-18, 2012.

7. David King, Keling Zhang, Liyu Li, Haobo Chen, Yuhua Duan, Shari Li, Prabhakar Singh; Carbon Capture-Promoted Syngas Utilization for Production of Fuels and Chemicals. Presented orally at the Eleventh Annual Conference on Carbon Capture, Utilization \& Sequestration, Pittsburgh, PA, May 2, 2012.

8. Liyu Li, Chris J. Howard, Baowei Chen, Shari X. Li, Haobo Chen, David L. King. Direct Hydrogen Production from Warm Coal and Biomass Syngas. Presented orally at the 28th Annual International Pittsburgh Coal Conference, Pittsburgh, PA, September 13, 2011.

9. Prabhakar Singh, Keling Zhang, Liyu Li, David L. King. Role of Double Salt Structure and Formulation on arm Temperature $\mathrm{CO}_{2}$ Capture. Presented orally at the 28th Annual International Pittsburgh Coal Conference, Pittsburgh, PA, September 15, 2011.

\subsection{Demonstrated technical results}

In parallel with the CAS-NETL-PNNL project, PNNL had obtained funding from the State of Wyoming to demonstrate syngas cleanup and $\mathrm{CO}_{2}$ capture-assisted methanation. This has been done in collaboration with the Western Research Institute, the organization that provided the gasifier for the demonstration, using a western (sub-bituminous) coal. In April, 2013, we demonstrated all the steps of the gas cleanup but not the $\mathrm{CO}_{2}$ capture-enhanced methanation. This was documented in a semiannual report, submitted to the State of Wyoming in June 2013. The latter unit operation, $\mathrm{CO}_{2}$ capture-enhanced methanation, will be added in a final demonstration, scheduled for April 2014.

\subsection{Recommended Next Steps, Collaborative Work}

Significant work remains in the development of the $\mathrm{CO}_{2}$ capture technology. Although $\mathrm{CO}_{2}$ capture is effective with either the $\mathrm{Na}_{2} \mathrm{CO}_{3}-\mathrm{MgO}$ or $\mathrm{CaCO}_{3}-\mathrm{MgO}$ systems plus $\mathrm{NaNO}_{3}$, the nitrate salt is oxidizing and corrosive. This is evidenced by corrosion spots appearing on the walls of the tubing in contact with the material. This occurs with stainless steel and even to some extent with Hastelloy C. This situation is alleviated working with alumina tubes; hence, the ultimate solution may be to operate with ceramic-lined fixed bed reactors. In addition, $\mathrm{CO}_{2}$ capture-assisted water gas shift or methanation requires a comingling of the capture material plus the metal catalyst. It is possible that the nitrate will oxidize the metal catalyst. Even if the oxidized metal catalyst is re-reduced, loss of $\mathrm{NaNO}_{3}$ will be the end result. Work to identify alternatives to molten nitrate salts needs to be supported and carried out, to determine their effectiveness, operating conditions, and other information. Collaborative work investigating fluid 
bed operation for the $\mathrm{CO}_{2}$ capture and release, rather than fixed bed operation, also needs to be examined as an option to deal with the significant temperature rise that can been encountered in the absorbent bed following $\mathrm{CO}_{2}$ absorption.

\subsection{References}

[1] P. Mondal, G.S. Dang, M.O. Garg; Syngas Production Through Gasification and Cleanup for Downstream Applications — Recent Developments; Fuel Processing Technology 2001, 92, 1395-1410.

[2] Nexant Report; Preliminary Feasibility Analysis of RTI Warm Gas Cleanup (WGCU) Technology; June 2007.

[3] Gupta, R.; Gangwal, S. K.; Jain, S. C. Development of Zinc Ferrite Sorbents for Desulfurization of Hot Coal Gas in a Fluid-Bed Reactor. Energy \& Fuels 1992, 6, 21.

[4] Lew, S.; Jothimurugesan, K.; Flytzani-Stephanopoulos, M. High Temperature $\mathrm{H}_{2} \mathrm{~S}$ Removal from Fuel Gases by Regenerable Zinc Oxide-Titanium Dioxide Sorbents. Ind. Eng. Chem. Res. 1989, $28,535$.

[5] E. Sasaoka, S. Hirano, S. Kasaoka, Y. Sakata, Energy \& Fuels, 8 (1994) 1100.

[6] H. Yang, R. Sothen, D. R. Cahela, B. J. Tatarchuk; Breakthrough Characteristics of Reformate Desulfurization Using ZnO Sorbents for Logistic Fuel Cell Power Systems; Ind. Eng. Chem. Res. 2008, 47, 10064-10070

[7] I. I. Novochinskii, C. Song, X. Ma, X. Liu, L. Shore, J. Lampert, R. J. Farrauto; Low-Temperature $\mathrm{H}_{2} \mathrm{~S}$ Removal from Steam-Containing Gas Mixtures with $\mathrm{ZnO}$ for Fuel Cell Application. 1. ZnO Particles and Extrudates; Energy \& Fuels, 18 (2004) 576.

[8] T. E. Graedel, G. W. Kammlott and J. P. Franey; Science, 1981, 212, 663-665.

[9] Sasaoka, E. Taniguchi, K., Uddin, A., Hirano, S., Kasaoka, S.,Sakata, Y.; Characterization of Reaction between ZnO and COS; Ind. Eng. Chem. Res. 1996, 35 (7), 2389-2394

[10] H. Huang, N. Young, B. P. Williams, S. H. Taylor, G. Hutchings; High temperature COS hydrolysis catalysed by $\mathrm{Y}$-A12O3; Catalysis Letters 2006, 110, (3-4), 243-246.

[11] K. Zhang, X. Li, Y. Duan, D. L King, P. Singh, L. Li.; Roles of Double Salt Formation and NaNO3 in $\mathrm{Na}_{2} \mathrm{CO}_{3}$-Promoted $\mathrm{MgO}$ Absorbent for Intermediate Temperature $\mathrm{CO}_{2}$ Removal. Int. J. Greenhouse Gas Control, 12 (2013) 351-358.

[12] X. Yang, L. Zhao, Y. Xiao; Effect of $\mathrm{NaNO} 3$ on $\mathrm{MgO}-\mathrm{CaCO}_{3} \mathrm{Absorbent}$ for $\mathrm{CO}_{2}$ Capture at Warm Temperature; Energy Fuels 2013, 27, 7645-7653. 


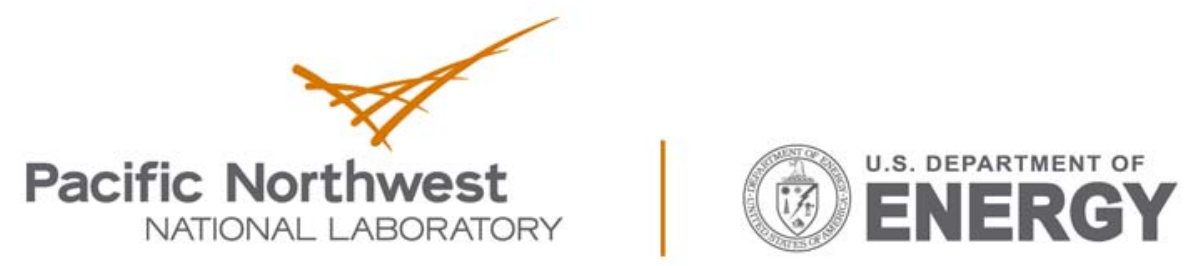

Proudly Operated by Battelle Since 1965

902 Battelle Boulevard

P.O. Box 999

Richland, WA 99352

1-888-375-PNNL (7665)

www.pnnl.gov 